\title{
Reputation and Reality in the ICSID Annulment Process: Understanding the Distinction Between Annulment and Appeal
}

\author{
David D. Caron ${ }^{*}$
}

ONE'S CHOICE OF INSTITUTIONAL FRAMEWORK for an international arbitration often turns, quite humanly, on rather intangible factors such as the institution's reputation. The influence of reputation can be frustrating both for the established and the new institution. As Shakespeare's Iago observed, "Reputation is an idle and most false imposition; oft got without merit, and lost without deserving." 1 Rumor is the handmaiden of a lost reputation. Vague statements circulate that a certain country is not a good choice as the place of arbitration or that a certain arbitral institution is biased towards the

1 William Shakespeare, Othello, act II, sc. 3. As to the sociology of rumor, see Goleman, Anatomy of a Rumor: Fear Feeds It, N.Y. Times, June 4, 1991, at B1.

* Professor of Law, Boalt Hall School of Law, University of California at Berkeley. B.S. 1974, United States Coast Guard Academy; M.Sc. 1980, University of Wales Centre for Marine Law and Policy; J.D. 1983, University of California at Berkeley; Dip. 1984, Hague Academy of International Law; Dr. jur. 1990, Drs. 1985, Leiden University. I wish to thank Professors Richard Bilder, Stephen Bundy, Joan Donoghue and Andrea Giardina for their valuable comments. I also wish to thank Amy Lowder, J.D. candidate 1993, and Steven Rosen, J.D. candidate 1992, Boalt Hall School of Law, University of California at Berkeley, for their assistance in the preparation of this article.

This paper was first presented at the Institute for Transnational Arbitration's Transnational Commercial Arbitration Workshop in Dallas, Texas on June 21, 1991. A number of papers addressing or touching upon the ICSID annulment issue have been published since that time. See, e.g., Broches, Observations on the Finality of ICSID Awards, 6 ICSID Rev.-FILJ 321 (1991). Reference to those articles has been made where appropriate. 
West. Herculean efforts are made to dispel such statements, but that often is not enough either to gain or maintain reputation.

A recent such vague statement concerns the International Centre for Settlement of Investment Disputes (ICSID). The gist of it is that there exists under Article 52 of the ICSID Convention a limited annulment process and that this process is running out of control, threatening the utility of ICSID ${ }^{2}$ Such a statement bears not only on the reputation of ICSID, but could also affect other international regimes, such as the GATT and the current discussions aimed at the creation of an appeal process for its panel decisions.

The following analysis concludes that the criticism of ICSID is misplaced. In Part I, I briefly explore an area central to a developed understanding of this process - the distinction between appeal and annulment. Part II seizes on this distinction and gives an account of the ICSID annulment process. In Part III, I explore and evaluate the concerns voiced over the ICSID annulment recourse. My message is fourfold: (1) much of the concern is dated; (2) some annulment process is desirable; (3) the present annulment process is not lengthy

2 The text of Article 52, and the earlier drafts of that provision, is reproduced in the Appendix to this article, infra at 55.

As to the literature on this question generally, see Feldman, The Annulment Proceedings and the Finality of ICSID Arbitral Awards, 2 ICSID Rev.-FILJ 85-110 (1987); Kahn, Le contrôle des sentences arbitrales rendues par un Tribunal CIRDI in La juridiction internationale permanente 363-82 (1987); Lattanzi, Convenzione di Washington sulle Controversie Relative ad Investimenti e Invalidità delle Sentenze Arbitrali, 70 Rivista di Diritto Internazionale 521-47 (1987); Niggemann, Das Washingtoner Weltbankübereinkommen von 1965-Das Nichtigkeitsverfahren im Ad-Hoc-Komitee, 4 Jahrbuch für die Praxis der Schiedsgerichtsbarkeit 97-120 (1990); Niggemann, Die dritte Annullierung eines ICSID-Schiedsspruches-Die Entscheidung in Sachen Mine v. Guinea, 11 IPRax 77 (Mar./Apr. 1991); Pirrwitz, Annulment of Arbitral Awards Under Article 52 of the Washington Convention on the Settlement of Investment Disputes Between States and Nationals of Other States, 23 Tex. Int'l L.J. 73-116 (1988); Redfern, ICSID-Losing Its Appeal?, 3 Arb. Int'l 98 (1987); Reisman, The Breakdown of the Control Mechanism in ICSID Arbitration, Duke L.J. 739-807 (1989); Seidl-Hohenveldern, Die Aufhebung von ICSID Schiedssprüchen, 1989 Jahrbuch für die Praxis der Schiedsgerichsbarkeit 100 (1989); Thibaut, L'article 52 de la Convention de Washington du 18 mars 1965 et les premiers enseignements de sa pratique, 1988 Revue de l'arbitrage 95-116; Schatz, The Effect of the Annulment Decisions in "Amco v. Indonesia" and "Klöckner v. Cameroon" on the Future of the International Centre for the Settlement of Investment Disputes, 3 Am. U. J. Int'l L. \& Pol'y 481515 (1988). For valuable comments outside indexed law journals, see also Branson, Annulments of "Final" ICSID Awards Raise Questions About the Process, Nat. L.J. (Aug. 4, 1986) at 25; Brower, Recent Developments (April 1, 1990-March 31, 1991) in The "Three I's" of International Arbitration: The Iran- United States Claims Tribunal, the ICC and ICSID (presented at a meeting of the Section of International Law and Practice of the American Bar Association, April 24-27, 1991) (transcript available from author).

As to the literature regarding proceedings following annulment, see Curtis, International Investment Disputes-Res Judicata Effect of Partially Annulled ICSID Awards, 83 AJIL 106 (1989); Rambaud, La compétence du Tribunal CIRDI saisi après une décision d'annulation, 34 Annuaire Francais de Droit International 209 (1988). 
when compared to other alternative dispute resolution mechanisms; and (4) the real problem to my mind lies not so much with the process, but rather with something more fundamental to transnational arbitration generally-the development of what is in fact a quasi-international judiciary.

\section{THE DISTINCTION BETWEEN APPEAL AND ANNULMENT}

Discussion of the ICSID annulment process by ad hoc committees repeatedly stresses that "the remedy...is in no sense an appeal."3 Discussions of the annulment decisions by commentators, however, often criticize the decisions as effectively being appeals. ${ }^{4}$ But the difference between an annulment and appeal process remains vague, and this vagueness confuses the task of ad hoc committee members and scholars alike. The following discussion examines both the conceptual distinction between annulment and appeal and the relationship of the functions of correcting decisions and managing judicial institutions to the processes of appeal and annulment.

\section{A. The Conceptual Distinction Between Appeal and Annulment}

Appeal and annulment are alike in that they are processes reviewing to some degree a judicial or arbitral decision. Their differences are less easy to note, however, because the particulars of these processes differ from one setting to another. Recognizing the consequent limits of any attempt at distinguishing the two review processes, they generally appear to be different in two ways. The first difference relates to the result of the process; the second, to the aspects of the decision that are subject to review. A third often mentioned, but in my view false, distinction is the standard of review used in either process. It is the second difference and the third false distinction that pervade the debate and confusion regarding the ICSID process.

The first distinction is not particularly controversial and is not an aspect of the confusion implicit in the discussions of the ICSID annulment process. The distinction nonetheless deserves a brief mention in this more general account of appeal and annulment. In particular, the potential results of the two review processes are different. In appeal, the decision under review not only may be confirmed, it more generally may be modified. In annulment, on the other hand, the decision under review only may be invalidated in whole or in part, or be left to stand if the plea for annulment is rejected. Annulment operates to negate

${ }^{3}$ Klöckner v. Cameroon: Decision of the Ad Hoc Committee, 1 ICSID Rev.-FILJ 90, 93 (1986) [hereinafter Klöckner Decision].

4 See, e.g., Pirrwitz, supra note 2, at 114 (arguing that, based on the Klöckner and Amco decisions, ICSID review "allows at least a partial examination of the merits").

Downloaded from https://academic.oup.com/icsidreview/article-abstract/7/1/21/774375

by Univ of California Library - Bioscience \& Natural Res Library user

on 26 February 2018 
a decision, in whole or in part, thereby depriving the portion negated of legal force and returning the parties, as to that portion, to their original litigating positions. Annulment can void, while appeal can modify $\rightarrow$ such modification including the negatation possible with annulment. Thus far there has been no question that the annulment process in ICSID can lead only to the voiding, as opposed to the modification, of all or a part of a decision. ${ }^{5}$

The second distinction between appeal and annulment reflects primarily a difference in the aspects of the legal decision subject to review. In distinguishing what aspects of the award are subject to review, I find it helpful to distinguish between the framework that yields the decision-what I term "legitimacy" of the process of decision - and the content of the decision-what I term substantive "correctness." A legitimate process of decision involves, for example, a body with authority to decide the dispute in question. Legitimacy of process might also require that the deciding body be properly constituted, not be corrupt, and observe fundamental rules of procedure. The substantive correctness of a decision in contrast is concerned with whether the decision reflects a sufficiently correct determination of the facts and application of the law to those facts. To illustrate, a decision on a securities issue may be substantively correct, yet not be the result of a legitimate process if rendered by a bankruptcy judge. Conversely, although a decision may be legitimate in the sense that surrounding framework and process are proper, the decision nonetheless may be substantively incorrect.

Bearing in mind that particular legal systems vary in their specifics, appeal generally focuses upon both the legitimacy of the process of decision and the substantive correctness of the decision. Annulment, on the other hand, and particularly in the case of arbitration, focuses not on the correctness of the decision, but rather more narrowly considers whether, regardless of errors in application of law or determination of fact, the decision resulted from a legitimate process. As will be seen, appeal and annulment can blur into one another because the

5 But see Reisman, supra note 2, at 792-95. Professor Reisman notes that in a partial annulment there is an implicit "confirmation" of those parts of the award not annulled. "[W]ith apologies for the lack of grace of the term, 'confirmatory,"' Reisman notes that the "rejection of a particular claim for nullification confirms the validity if not the correctness of that part of the challenged award." Id . at 793 (emphasis added). More broadly, "confirmation" of a decision in either an appeal or annulment process should not be equated with agreement with the decision. The degree of agreement is related to the standard of review present in the review process. This observation is important in the case of ICSID where the standard of review employed in the annulment process generally is not high enough to necessarily imply agreement. For example; the standard of review for certain aspects of a decision considered in the ICSID annulment process is manifest error. An ad hoc committee operating under this standard might conclude that the tribunal exceeded its powers but did not manifestly do so. In such an instance, although the ad hoc committee would not annul and thus in essence "confirm," that decision, it also does not agree with the decision. 
former subsumes the latter and because a decision that is grossly incorrect could be viewed as evidence of an illegitimate process.

The difference in focus between appeal and annulment can be explored through the examples of national judiciaries and arbitration. In the case of national judiciaries, there is most often a hierarchial court structure with courts of appeal reviewing both substantive correctness and legitimacy of process. In the civil law countries this process often involves a trial de novo both as to questions of law and fact, while in common law countries the review is de novo as to law, but more limited regarding the facts. ${ }^{6}$ In the case of arbitration, the parties through their agreement create an entirely different situation because regardless of how complex or simple a dispute resolution mechanism they create, they almost always agree that the resultant award will be final and binding upon them. In other words, regardless of whether there are errors of application of law or ascertainment of fact, the parties agree that the award will be regarded as substantively correct. Yet, although the content of the award is thus final, parties may still challenge the legitimacy of the decision-making process leading to the award. In essence, parties are always free to argue that they are not bound by a given "award" because what was labelled an award is the result of an illegitimate process of decision.

This is the core of the notion of annulment in arbitration. In a sense, annulment is all that doctrinally survives the parties' agreement to regard the award as final and binding. Given the agreement of the parties, annulment requires a challenge to the legitimacy of the process of decision, rather than the substantive correctness of the award. Of course, in a particular regime, an "annulment" process may not follow strictly this distinction between legitimacy of process and correction of the decision. For example, if a basis for challenging the legitimacy of process in a specific "annulment" regime leads one into an examination of correctness, then for that basis the distinction between annulment and appeal to some degree collapses. As will be seen, such a blurring of annulment into appeal looms in the case of ICSID because the ground for annulment in ICSID of "failure to state reasons" "can quite easily lead an ad hoc committee to examine the content of the award.

In general, grounds for challenging the process leading to the award allege that the tribunal acted outside its scope of authority, thus denying legitimacy to the award; or that the tribunal was improperly constituted or corrupt, thus

6 See generally M. Shapiro, Courts: A Comparative and Political Analysis 37-64 (1981) (comparing court systems in civil and common law jurisdictions). It should be noted that civil law systems in annulment proceedings generally do not review questions of fact. Letter from Professor Andrea Giardina, June 2, 1992.

7 See Convention on the Settlement of Investment Disputes between States and Nationals of Other States (ICSID Convention), opened for signature March 18, 1965, 17 U.S.T. 1270, T.I.A.S. No. 6090, 575 U.N.T.S. 159, art. 52.

Downloaded from https://academic.oup.com/icsidreview/article-abstract/7/1/21/774375

by Univ of California Library - Bioscience \& Natural Res Library user

on 26 February 2018 
tainting the process and any resultant award. ${ }^{8}$ Such grounds do not require an inquiry into the substantive correctness of the decision, but rather an inquiry (1) into whether the tribunal was properly constituted; (2) into the correctness of some antecedent decisions as to the tribunal's range of action-for example, jurisdiction or applicable law; (3) into whether the tribunal was corrupt; and (4) into whether due process was afforded the parties. Importantly, a court of appeal also could hear such a plea for annulment. A court may review a decision as to jurisdiction, and if it concludes that jurisdiction was lacking, the trial court's decision will be vacated, or in other words, annulled. Thus, as stated at the outset, appeal generally embraces an inquiry both into the substantive correctness and legitimacy of process, while annulment generally is an inquiry limited to legitimacy of process.

The third, and in my view false, distinction between appeal and annulment is implied in the loose assertion that annulment does not seek to substitute the judgment of the second panel for that of the first. In one sense, the assertion is merely a restatement of the idea that annulment does not inquire into the substantive correctness of an award. The assertion is false, however, if it extends beyond the area of review to the standard of review. In particular, there is no apparent reason why the second distinction between appeal and annulment discussed above should necessarily imply a certain standard of review for either process. An appeal inquiry into the correctness of the ascertainment of facts may be de novo or may simply require that the lower court's finding be supported by the preponderance of the evidence. Likewise, an annulment inquiry into the jurisdictional basis of an award could be de novo or limited to whether the tribunal's holding is manifestly in excess of the scope of powers delegated to the tribunal. ${ }^{9}$ The standard of review in this way defines "the balance of power" between the trial court or tribunal and the appeal or annulment body. 10

\section{B.The Relationship Between the Functions of Correcting Decisions and Managing} Judicial Institutions and the Processes of Appeal and Annulment

At least two objectives for a dispute resolution system may be served by having decisions of that system reviewed. First, there is the objective of ensuring that

8 See, e.g., UNCITRAL Model Law on International Commercial Arbitration, art. 34, adopted June 21, 1985, reprinted in 24 ILM 1302, 1311 (1985). See generally H. Holtzmann \& J. Neuhaus, A Guide to the UNCITRAL Model Law on International Commercial Arbitration (1989)

${ }^{9}$ For example, Article V of the Convention on the Enforcement and Recognition of Foreign Arbitral Awards (New York Convention), opened for signature June 10, 1958, 21 U.S.T. 2517, T.I.A.S. No. 6997,330 U.N.T.S. 3, does not require, as the ICSID Convention does, that the lack of jurisdiction be manifest.

10 See Shapiro, supra note 6, at 39 ("Trial de novo, of course, gives an appellate court far more general supervisory power"). 
the parties in a particular dispute receive a substantively correct and legitimately arrived at decision. Second, there is the objective of maintaining some control, in particular, quality control, over the court or arbitration system. Clearly, these two objectives overlap, but not entirely. Just as to encourage the honest preparation of tax returns, one need not audit every return; so too to maintain quality control, one need not grant a right of appeal or annulment in every case.

Viewed in such functional terms, the presence of a right of review, the scope of the review, and the standard of review of the reviewing body all become indicative of the emphasis implicit in the overall design of the review. Annulment of arbitral awards is difficult to analyze in these functional terms because the parties, in agreeing that the award is final, could be taken to have expressed that they do not desire a review of substantive correctness. Thus the scope of the first function is reduced to ensuring a legitimate process of decision, unless (and this is important) a broader community decides thatregardless of the parties' wishes - that community has independent reasons to ensure the substantive correctness of decisions. ${ }^{11}$

In this way, arbitral annulment can be seen as a doctrinal consequence of a private conception of dispute resolution. Importantly, although ICSID is a community institution, the drafters of the ICSID Convention basically institutionalized the review process that accompanied the private conception. As discussed in Part III, I believe the international community has a greater interest in substantive correctness of ICSID awards than is implicit in the annulment process provided for in Article 52. This is in no way an assertion that the drafters of the ICSID Convention intended or adopted anything other than a form of annulment. Rather it reflects my belief that the public importance of the disputes before ICSID could have justified an even more exacting process.

\section{APPLYING THE APPEAL/ANNULMENT DISTINCTION: AN ACCOUNT OF THE ANNULMENT PROCESS}

The ICSID Convention ${ }^{12}$ was opened for signature on March 18, 1965 and entered into force on October 14, 1966. Since the Centre commenced operations in 1966, twenty-four disputes have been registered as arbitrations with

11 See Caron, International Dispute Resolution: Comparing the Roles Accorded the Parties and the Community Surrounding Them, Proceedings, 85th Annual Meeting of the American Society of International Law 65 (1992).

12 See ICSID Convention, supra note 7. As of April 15, 1992, there were 98 States parties to the Convention. See List of Contracting States and Other Signatories of the Convention, Doc. ICSID/3 (Mar. 9, 1992). For an extensive bibliographical guide to ICSID, see ICSID Bibliography, Doc. ICSID 13/Rev. 2 (Mar. 1, 1992).

Downloaded from https://academic.oup.com/icsidreview/article-abstract/7/1/21/774375

by Univ of California Library - Bioscience \& Natural Res Library user

on 26 February 2018 
the Centre. Of these, ten were discontinued for some reason prior to the issuance of an award. ${ }^{13}$ One resulted in an award embodying a settlement by the parties. ${ }^{14} \mathrm{~A}$ further two arbitrations remain pending their first award. ${ }^{15}$ Consequently, only eleven of the twenty-four disputes involved the possibility of annulment. The proceedings in these eleven disputes are summarized in Table 1.

\section{Table 1}

\section{ICSID Arbitrations Bearing on Annulment}

\begin{tabular}{|c|c|c|c|}
\hline Case Name & Date Registered & Date of Award & Annulment Reco \\
\hline $\begin{array}{l}\text { Adriano Gardella v. } \\
\text { Côte d'Ivoire } \\
\text { Case ARB/74/1 }\end{array}$ & Mar. 6, 1974 & Aug. 29, 1977 & \\
\hline $\begin{array}{l}\text { AGIP SpA v. } \\
\text { Congo } \\
\text { Case ARB/77/1 }\end{array}$ & Nov. 4, 1977 & Nov. 30, 1979 & \\
\hline $\begin{array}{l}\text { Benvenuti \& } \\
\text { Bonfant v. Congo } \\
\text { Case ARB/77/2 }\end{array}$ & Dec. 15,1977 & Aug. 8,1980 & \\
\hline $\begin{array}{l}\text { Amco Asia v. } \\
\text { Indonesia } \\
\text { Case ARB/81/1 }\end{array}$ & Feb. 27, 1981 & $\begin{array}{l}\text { Nov. 20, } 1984 . \\
\text { Interlocutory } \\
\text { Award on Juris. } \\
\text { Sept. 25, } 1983\end{array}$ & $\begin{array}{l}\text { Req. of Indonesia } \\
\text { reg. Apr. } 18,1985 \\
\text { Partial annulment, } \\
\text { May } 16,1986\end{array}$ \\
\hline
\end{tabular}

13 The following cases were discontinued prior to a final award: Holiday Inns/Occidental Petroleum v. Morocco (ICSID Case No. ARB/72/1) (discontinued Oct. 17, 1978 following settlement); Alcoa Minerals of Jamaica, Inc. v. Jamaica (ICSID Case No. ARB/74/2) (discontinued Feb. 27, 1977 following settlement); Kaiser Bauxite Co. v. Jamaica (ICSID Case No. ARB/74/3) (discontinued Feb. 27, 1977 at request of Claimant following agreement with Respondent); Reynolds Jamaica Mines, Ltd. v. Jamaica (ICSID Case No. ARB/74/4) (discontinued Oct. 12, 1977 at Claimant's request); Gabon v. Société Serete S.A. (ICSID Case No. ARB/76/1) (discontinued Feb. 27, 1978 following settlement); Swiss Aluminum Ltd. v. Iceland (ICSID Case No. ARB/83/ 1) (proceedings suspended Oct. 3, 1983 by agreement of parties); Colt Industries v. Korea (ICSID Case No. ARB/84/2) (discontinued Aug. 3, 1990 following settlement); Dr. Ghaith R. Pharaon v. Tunisia (ICSID Case No. ARB/87/1) (discontinued Nov. 21, 1988 following settlement); Occidental of Pakistan v. Pakistan (ICSID Case No. ARB/87/4) (discontinued at request of Occidental following settlement); Mobil Oil v. New Zealand (ICSID Case No. ARB/87/2) (Centre notified of settlement by the parties on July 10, 1990 following the Tribunal's initial findings on liability).

14 See Guadalupe Gas Products v. Nigeria (ICSID Case No. ARB/78/1).

15 The following cases are pending their first final award: SETIMEG S.A. v. Congo (ICSID Case No. ARB/87/1); Manufacturers Hanover Trust v. Egypt (ICSID Case No. ARB/ 89/1). Southern Pacific Properties (SPP) v. Egypt (ICSID Case No. ARB/84/3) is pending the decision in its first annulment proceeding. Amco Asia Corp. v. Indonesia (ICSID Case No. $\mathrm{ARB} / 81 / 1)$ is pending the decision in its second annulment proceeding. See infra note 17. 
Table 1 Continued

\begin{tabular}{|c|c|c|c|}
\hline Case Name & Date Registered & Date of Award & Annulment Recourse \\
\hline (Amco ctd.) & $\begin{array}{l}\text { Resubmitted } \\
\text { May } 21 \text { and } \\
\text { June } 24,1987\end{array}$ & $\begin{array}{l}\text { June } 5,1990 \\
\text { (lesser amount } \\
\text { than in first award) }\end{array}$ & $\begin{array}{l}\text { Requests of both } \\
\text { parties reg. Oct 18, } \\
1990, \text { decision } \\
\text { pending }\end{array}$ \\
\hline \multirow[t]{2}{*}{$\begin{array}{l}\text { Klöckner v. } \\
\text { Cameroon } \\
\text { Case ARB/81/2 }\end{array}$} & Apr. 14,1981 & Oct. 21, 1983 & $\begin{array}{l}\text { Req. of Klöckner } \\
\text { reg. Feb. 16, } 1984 . \\
\text { Award annulled } \\
\text { May 3, } 1985\end{array}$ \\
\hline & $\begin{array}{l}\text { Resubmission } \\
\text { Requests of } \\
\text { both parties reg. } \\
\text { June } 7 \text { and } \\
\text { July } 3,1985\end{array}$ & Jan. 26, 1988 & $\begin{array}{l}\text { Requests of both } \\
\text { parties reg. July } 1 \text {, } \\
\text { 1988. Both annul- } \\
\text { ment requests denied } \\
\text { June } 4,1990\end{array}$ \\
\hline $\begin{array}{l}\text { SOABI v. } \\
\text { Senegal } \\
\text { Case ARB/82/1 }\end{array}$ & Nov. 5, 1982 & Feb. 25,1988 & \\
\hline $\begin{array}{l}\text { LETCO v. } \\
\text { Liberia } \\
\text { Case ARB/83/2 }\end{array}$ & June 21,1983 & Mar. 31, 1986 & \\
\hline $\begin{array}{l}\text { Atlantic Triton v. } \\
\text { Guinea } \\
\text { Case ARB/84/1 }\end{array}$ & June 19, 1984 & Apr. 21, 1986 & \\
\hline \multirow[t]{2}{*}{$\begin{array}{l}\text { Southern Pacific } \\
\text { Properties v. } \\
\text { Egypt } \\
\text { Case ARB } / 84 / 3\end{array}$} & Aug. 28, 1984 & $\begin{array}{l}\text { Decision on } \\
\text { Jurisdiction, } \\
\text { Apr. 14, 1988, } \\
\text { with dissent }\end{array}$ & $\begin{array}{l}\text { Req. of Egypt } \\
\text { rec'd Nov. 14, } 1988 . \\
\text { Reg. declined Dec. 9, } \\
1988 \text { (not an "award") }\end{array}$ \\
\hline & & May 20,1992 & $\begin{array}{l}\text { Req. of Egypt } \\
\text { reg. May 27, 1992, } \\
\text { decision pending }\end{array}$ \\
\hline \multirow[t]{2}{*}{$\begin{array}{l}\text { MINE v. Guinea } \\
\text { Case ARB } / 84 / 4\end{array}$} & Sept. 18,1984 & Jan. 6, 1988 & $\begin{array}{l}\text { Request of Guinea reg. } \\
\text { Mar. } 30,1988 \text {. Annulled } \\
\text { as to amount of damages, } \\
\text { Dec. } 22,1989\end{array}$ \\
\hline & $\begin{array}{l}\text { Resubmitted } \\
\text { Jan. } 26,1990\end{array}$ & Discontinued & \\
\hline $\begin{array}{l}\text { Asian Agricultural } \\
\text { v. Sri Lanka } \\
\text { Case ARB } / 87 / 3\end{array}$ & July 20,1987 & June 27, 1990 & \\
\hline
\end{tabular}


For the first three of these eleven disputes arbitrated, no application for annulment was made to the Centre. Since the Award rendered in Klöckner v. Cameroon ${ }^{16}$ on October 21,1983 , however, there has been considerable annulment activity. For those remaining eight disputes, there has been not only the eight initial arbitrations but also the arbitrations of two of these disputes resubmitted following annulment, a total of ten arbitration proceedings. Of the total thirteen final Awards rendered in the eleven disputes,

there have been six annulment proceedings: twice in Klöckner, twice in

16 Klöckner GmbH v. Cameroon (ICSID Case No. ARB/81/2).

The dispute arose from a joint venture between a multinational corporation, Klöckner, and a developing country, Cameroon, to establish a fertilizer product manufacturing plant in Cameroon. The factory's production in its first several years was far less than expected. The parties disagreed as to which of them was responsible. Ultimately, Klöckner initiated the ICSID proceedings for certain payments guaranteed by Cameroon. Cameroon counterclaimed asserting that Klöckner had violated various obligations, primarily ones under a management contract. But, given that the contract provided for ICC arbitration, the jurisdiction of ICSID over the counterclaim was contested.

A majority of the Tribunal concluded that (1) it had jurisdiction over the counterclaim by virtue of the basic project agreement, not the management agreement; (2) French civil law as incorporated in Cameroonian law applied; and (3) a general principle of French law permitted a party to refuse to perform its contractual obligations when confronted with a material failure to perform by the other party. Consequently, the Tribunal dismissed the claim of Klöckner and the counter-claim of Cameroon. Professor Dominique Schmidt, the arbitrator appointed by Klöckner, dissented in a lengthy opinion, arguing the Award was null because of "important mistakes" and "numerous contradictions and failures to state the grounds" for the Award.

The Award was rendered on Oct. 21, 1983 (in French) and is reprinted at 111 Journal du Droit International 409 (1984). The Award is quoted extensively in English translation by Paulsson in The ICSID Klöckner v. Cameroon Award: The Duties of Partners in North-South Economic Development Agreements, 1 J. Int'l Arb. 145 (1984). See also Niggemann, The ICSID Klöckner v. Cameroon Award: The Dissenting Opinion, 1 J. Int'l Arb. 331 (1984) and Thompson, The Klöckner v. Cameroon Appeal: A Note on Jurisdiction, 3 J. Int'l Arb. 93 (1986).

Many commentators who have studied the award have been critical of it. "The award was unquestionably problematic in terms of craftsmanship and reasoning." Reisman, supra note 2 , at 760. "[A] poorly drafted, almost obnoxious award." Pirrwitz, supra note 2, at 114.

The Award was annulled by an ad hoc committee. For an English translation of the Decision of the ad hoc Committee in Klöckner, see supra note 3. 
Amco v. Indonesia, ${ }^{17}$ once in MINE v. Guinea, ${ }^{18}$ and once in Southern Pacific Properties v. Egypt. ${ }^{19}$ This section examines what Article 52(1) means in light of these annulment proceedings and an interlocutory annulment

17 Amco Asia Corp. v. Indonesia (ICSID Case No. ARB/81/1).

The dispute stemmed from a 1968 agreement between Amco and an Indonesian private company with ties to the Indonesian military to build and operate a hotel. Disputes subsequently arose and in 1980 Amco's foreign investment license was revoked and the management was ousted from the hotel with assistance of army and police personnel. Amco's application to ICSID was registered on Feb. 27, 1981 claiming approximately nine million dollars plus interest for the loss of its property. The Tribunal in its Award of Nov. 20, 1984 unanimously held that the Government of Indonesia had not properly terminated Amco's foreign investment license awarding the claimant $\$ 3,200,000$ plus interest.

The text of the Nov. 20, 1984 Award is reprinted in part at 1 Int'l Arb. Rep. 601 (1986); excerpts are reprinted in 24 ILM 1022 (1985). The interlocutory Decision on jurisdiction is reprinted in 23 ILM 351 (1984) and 10 Y.B. Com. Arb. 61 (1985); and the Decision as to the request for provisional measures is reprinted at 24 ILM 365 (1985).

The Decision of the ad hoc Committee in Amco is reprinted in 25 ILM 1441 (1986) [hereinafter Amco Decision].

The Decision of May 10, 1988 on jurisdiction in the resubmitted case is reprinted in 3 ICSID Rev.-FILJ 166 (1988) and noted at Curtis, supra note 2. The second Award of June 5, 1990 is reprinted in 5 Int'1 Arb. Rep. No. 11 (Nov. 1990).

18 Maritime International Nominees Establishment (MINE) v. Guinea (ICSID Case No. $\mathrm{ARB} / 84 / 4)$.

The dispute arose from a 1972 agreement between MINE and the Government of Guinea which created a joint-venture company (SOTRAMAR) that was to transport bauxite. When the relationship with MINE failed to result in any shipping arrangements, Guinea entered into a separate agreement with another transportation company, Afrobulk, to export the bauxite. MINE initiated arbitration proceedings with ICSID, and the dispute was registered on Sept. 18, 1984. MINE claimed that Guinea was responsible for SOTRAMAR's failure because it had refused to grant SOTRAMAR's management the authority necessary to negotiate and conclude contracts. MINE also argued that Guinea had breached the agreement by its arrangement with Afrobulk. In response, Guinea claimed that MINE had breached the contract by failing to complete any affreightment or charter contracts.

The Tribunal unanimously concluded that Guinea had prevented SOTRAMAR from performing as stipulated under the agreement, and thus had breached the contract. The Tribunal found that Guinea's alternate arrangements with Afrobulk had violated the agreement as well.

Guinea requested annulment of these findings on the grounds that: (1) the Tribunal had manifestly exceeded its powers, and (2) the Tribunal had failed to state the reasons for its decision. The ad hoc Committee annulled the Award as to the quantum of damages. The Decision of the ad hoc Committee is reprinted in 5 ICSID Rev.-FILJ 95 (1990).

${ }^{19}$ Southern Pacific Properties Ltd. v. Egypt (ICSID Case No. ARB/84/3). 
request in Southern Pacific Properties v. Egypt, which was not accepted for registration (also summarized in Table 1). ${ }^{20}$

The meaning of Article 52(1) has been explored in the four ad hoc Committee Decisions on applications for annulment rendered thus far. Commentaries have focused primarily upon the first two of these Decisions, the May 3, 1985 Decision in Klöckner and the May 16, 1986 Decision in Amco, although a recent article also analyzed the December 22, 1989 Decision in MINE v. Guinea. ${ }^{21}$ Although each of the four Decisions may be persuasive to later ad hoc committees, ${ }^{22}$ the MINE v. Guinea Decision may be particularly important given that (1) Aron Broches, the first Secretary-General of ICSID, served as a member of the ad hoc Committee and (2) Sompong Sucharitkul served as Chairman of the annulment proceedings not only in MINE, but also in Klöckner II and Amco II (the latter of which remains pending at the time of publication of this article). ${ }^{23}$ The last of the four Decisions, the second Decision in Klöckner II rendered on June 4, 1990, had not yet been released to the public domain by the parties at the time of this writing and is thus not included in the following analysis. ${ }^{24}$

The previous commentaries on the Klöckner and Amco Decisions have tended to enter into a detailed review of the arbitrations and annulment proceedings, laying the basis for a critique of the particular annulment decision under consideration. ${ }^{25}$ In the following analysis, I instead focus on how the

20 Six annulment proceedings for thirteen final awards represents an annulment proceedings rate of slightly less than half $(46 \%)$. From the perspective of there having been annulment proceedings in four of the eleven disputes that reached a final award, the rate would be $31 \%$. Unfortunately, it is beyond the scope of this paper to glean significantly more from this simple observation. Should the three arbitrations before Klöckner be discounted because the parties and their counsel did not fully appreciate the possibility of annulment? Conversely, will "future losers in ICSID arbitrations," as Professor Reisman suggests, "be hard-pressed not to exercise their option under Article 52?" Reisman, supra note 2 , at 787 . How does the possibility of an annulment request affect negotiations as to satisfaction of the award? Would a detailed study of all thirteen arbitrations find a significant relationship between the substantive correctness of the award and the presence of an application for annulment? Overall, I tend to agree with the MINE Committee that "[a] pure statistical approach, for which there is in any event no significant basis at the present time, is wholly inappropriate as a measure of ICSID's effectiveness." MINE Decision, supra note 18 , at para. 4.12.

21 See, e.g., Broches, Observations on the Finality of ICSID Awards, 6 ICSID Rev.-FILJ 321 (1991) (discussing the MINE Decision in light of the Klöckner and Amco Decisions).

22 See Amco Decision, supra note 17, para. 44 ("The absence, however, of a rule of stare decisis in the ICSID arbitration system does not prevent this ad hoc Committee from sharing the interpretation given to Article 52(1)(e) by the Klöckner ad hoc Committee").

23 The composition of ad hoc committees generally is set out in Table 2, infra.

24 I note, however, that it is my understanding that the reasoning of the Klöckner II annulment Decision follows closely that set forward in the MINE Decision.

25 See, e.g., Pirrwitz, supra note 2. 
Klöckner, Amco and MINE ad hoc Committees have interpreted Article 52 and thus their mandates. This is not to say that the critique of individual cases is not important because, as discussed at the outset of Part I, the interpretations of Article 52 in Klöckner and Amco put forward a distinction between "annulment" and "appeal" that was difficult to apply in practice. Regarding previous critiques of Klöckner and $A m c o$, it is sufficient for our present purposes to note that (1) the Award in Klöckner was widely criticized, and although one would expect as a consequence that the Decision of the Klöckner ad hoc Committee annulling the Award would have been welcome, that Decision likewise was criticized for both its interpretation of Article 52 and its seeming lack of restraint; and (2) while the Award in Amco was not as criticized as that rendered in Klöckner, the Decision of the Amco ad hoc Committee was viewed by many as too closely approaching an appeal of the Tribunal reasoning. ${ }^{26}$

The basic approach of the three ad hoc Committee Decisions to the task of interpreting Article 52 is the same: all three of the Decisions agree that Article 52 should be interpreted in accordance with the law of treaties. ${ }^{27}$ Consequently, the ad hoc Committee in MINE, for example, rejected suggestions that Article 52 should be either broadly or narrowly construed, but rather that it "should be interpreted in accordance with its object and purpose...."28 Similarly, this approach to interpretation led to the conclusion that Article 52 should "be interpreted in the context of the Convention," 29 so as "to achieve a harmonious balance between the various objectives of the Convention." 30

With these preliminary observations in mind, I turn to observations of the ICSID review process based on the interpretations offered by these three annulment Decisions. The discussion proceeds along three lines. First, the basic

26 Id. at 114 ("a clearly unnecessary, erroneous and excessive annulment decision...").

27 See Klöckner Decision, supra note 3, at para. 58 ("in accordance with principles of interpretation that are recognized generally-for example, by Article 31 of the Vienna Convention on the Law of Treaties"). Amco Decision, supra note 17, at para. 18 ("Problems of interpretation or lacunae which emerge have to be solved or filled in accordance with the principles and rules of treaty interpretation generally recognized in international law").

28 MINE Decision, supra note 18, at para. 4.05. See also Klöckner Decision, supra note 16 , at para. 3 ("neither a narrow interpretation, nor a broad interpretation").

29 Klöckner Decision, supra note 3, at para. 58.

30 Id. at para. 3.

As will be seen, this generally salutary contextual approach, coupled with a more questionable application of the "principle of effectiveness," led to the conclusion that the annulment recourse was intended to be a remedy for breaches of other articles of the ICSID Convention because "it is impossible to assume that the authors of [the other articles] would have neglected to consider the sanction for non-compliance [with those other articles]." Id. at paras. 58 and 62 . As to the effectiveness principle, see, e.g., Lauterpacht, Restrictive Interpretation and the Principle of Effectiveness in the Interpretation of Treaties, 26 Brit. Y.B. Int'l L. 49 (1949). 
contours of ICSID's annulment process are developed. Second, the specific language of ICSID Article 52 is parsed to reveal the confusion between the concepts of annulment and appeal. Finally, the automaticity of annulment if a ground for annulment is found to exist is explored. The discussion reveals that: (1) an analysis of the basic ICSID review framework belies ICSID's current reputation for instability, that is, an analysis of Article 52(1) demonstrates that the review procedures' essential structure supports the integrity of the ICSID process; (2) the perception of the ICSID annulment process as shading into appeal is fueled and justified in part by the language of Article 52(1)(e), which seemingly invites scrutiny of tribunal decisions not only in terms of the legitimacy of the process of decision but also in terms of substantive correctness; and (3) the perception of the ICSID review process as being out of control resulted in large part from the, apparently now-reversed, approach of the first two Decisions as to the automaticity of annulment if a ground for annulment to any degree is found to exist.

\section{A. The Basic Contours of the Annulment Process}

The ICSID annulment process, like the prototypical annulment process, provides a quite limited remedy. This section examines the nature of the remedy, the availability of partial annulment and, quite significantly, the unavailability of interlocutory annulment.

\section{The Nature of the Remedy and the Presumed Validity of the Award}

All three Decisions stress that the process is one of annulment, not appeal. "[T]he remedy...is in no sense an appeal."31 But, as noted in Part I, none of the Decisions clearly differentiates annulment from appeal. MINE goes the furthest towards providing a distinction when it stresses that Article 52 provides a limited remedy in the sense that it "is not a remedy against an incorrect decision." 32 Consequently, annulment cannot "be used by one party to complete or develop an argument which it could and should have made during the arbitral proceedings or help that party retrospectively to fill gaps in its arguments." 33

The limited nature of the annulment remedy is generally apparent from the self-contained nature of the ICSID regime. The MINE Committee emphasized the limited nature of available remedies, noting that Article 53 provides that awards "shall not be subject to any appeal or to any other remedy except those provided for in this Convention," thus barring any review in national courts. The Committee then observed that, "even within the framework

31 Id. at para. 3 (emphasis in original).

32 MINE Decision, supra note 18, at para. 4.04. Accord Klöckner Decision, supra note 3, at para. 83

33 Klöckner Decision, supra note 3 , at para. 83.

Downloaded from https://academic.oup.com/icsidreview/article-abstract/7/1/21/774375

by Univ of California Library - Bioscience \& Natural Res Library user

on 26 February 2018 
of the Convention [the Award] is not subject to review on the merits." 34 The Committee noted that the Award is not final only "in the sense that it is open to being completed or corrected, interpreted, revised or annulled." 35 As the MINE ad hoc Committee recounted:

The post-award procedures (remedies) provided for in the Convention, namely, the addition to, and correction of, the award (Art. 49), and interpretation (Art. 50), revision (Art. 51) and annulment (Art. 52) of the award are to be exercised within the framework of the Convention and in accordance with its provisions. ${ }^{36}$

In short, Article 52 is a limited remedy in that (1) the ICSID review process is one of annulment, not appeal, and (2) the grounds for such annulment are "listed exhaustively" in Article 52(1). ${ }^{37}$

\section{The Availability of Partial Annulment}

The ad hoc committee's power to annul an award in part is expressly granted in Article 52(3). In the Klöckner Committee's view, this authority is a logical consequence of the finality and attendant presumed validity of the award:

In concrete terms, the question is whether, applying the principle of favor validitatis or "partial annulment of legal acts," only a part of the contested award should be annulled, or whether it should be annulled in its entirety.

Generally, speaking, partial annulment would seem appropriate if the part of the Award affected by the excess of powers is identifiable and detachable from the rest, and if so, the remaining part of the Award has an independent basis. 38

34 MINE Decision, supra note 18 , at para. 4.02.

35 Id.

36 Id.

37 Klöckner Decision, supra note 3, at para. 3. Article 52(1) provides "[e]ither party may request annulment... on one or more of the following grounds."

In the 1986 ICSID Annual Report, after two awards had been annulled, Secretary-General Ibrahim Shihata emphasized the limited nature of annulment as a remedy, noting that, "an award is not open to attack on any ground in the Court of the Contracting State. Because of this, the drafters of the Convention felt it proper to provide special remedies, independent from any domestic legal system which gave the parties the assurance that, should an arbitral tribunal deviate from the rules set forth in the Convention, the matter can be the object of impartial consideration by an independent body.... It can only be hoped that recourse to this remedy will remain, as it has been to the present, the exception." 1986 ICSID Ann. Rep. at 4.

After the MINE annulment proceeding was registered, the Secretary-General wrote in the 1988 Annual Report (p. 4) that "in keeping with the intention of the drafters of the ICSID Convention, recourse to this [annulment] procedure has remained exceptional. However, the ICSID system would obviously suffer if a trend emerges in the future of unjustifiable recourse to the annulment procedure in the ICSID arbitral process. Should this become the case, the Administrative Council may...wish to consider ways in which to clarify the exceptional nature of the annulment procedure." 1988 ICSID Ann. Rep. at 4.

38 Klöckner Decision, supra note 3, at para. 80 (emphasis in original). 
An example of a portion of the award not easily detachable from the remainder is the MINE Committee's analysis of costs. The Committee concluded that if the damage portion of an award has been annulled, then the award of costs must be annulled as well, since it is "inextricably linked" 39 to such a finding.

Whether the lesser included remedy of partial annulment open to the ad hoc committee may be requested as an initial matter by a party is not entirely clear. For the reasons which follow, however, I conclude that a party invoking the annulment mechanism should not by its petition be able to limit the scope of examination. Although Article 52(1) provides only that a party "may request annulment of the award," the MINE ad hoc Committee in the sole instance of practice held Guinea's request for partial annulment admissible inasmuch as Article 52(3) authorizes the Committee "to annul the award or any part." 40 On this point, I believe the Committee confused its authority to partially annul an award with the obligation of the requesting party to make its request for annulment as to the whole award. Indeed, this confusion is apparent in the reasoning of the MINE Decision. On the one hand, the MINE Decision appears to imply that if a party requests only a partial annulment, then the remaining portion cannot be examined by the Committee:

[The application for annulment] does not request annulment of the portion of the Award adjudging Guinea's counter-claim. Nor, for that matter, has annulment of that portion been requested by MINE. That portion of the Award will remain in effect regardless of the annulment in whole or in part of the portion of the Award in respect of which Guinea has formulated its request for annulment. ${ }^{41}$

On the other hand, the Committee also noted that, "by necessary implication," $" 42$ annulment of any part of an award might require annulment of portions not within the scope of a request.

Perhaps the MINE ad hoc Committee wished to avoid holding Guinea's request for partial annulment to be inadmissible on such formal grounds. If so, their decision should have been that formal flaws in a request for annulment may be remedied by amendment. A general request for annulment where the requesting party then argues the annulment need only be partial is not equivalent to that party simply requesting a partial annulment. The difference is in the scope of questions presented and the briefings suggested. I can not say with any certainty that the MINE Committee's holding will lead to serious problems

${ }^{39}$ MINE Decision, supra note 18 , at para. 6.112 .

40 Id. at para. 4.07 (citing Arbitration Rule 55(3): "the new Tribunal shall not reconsider any portion of the award not so annulled").

41 Id. at para. 4.07 (emphasis added).

42 Id. at para. 4.08 . 
in later annulment proceedings. But, it does not appear to be supported by the language of Article 52 and may encourage strategic thinking on the part of the parties that can only confuse annulment proceedings.

\section{The Unavailability of Interlocutory Annulment}

One of the most important decisions relating to the annulment recourse was not decided by an ad hoc committee, but rather by the ICSID Secretariat.

In Souther Pacific Properties v. Egypt, ${ }^{43}$ the Tribunal rendered a decision on all jurisdictional issues on April 14, 1988. In response to the Tribunal holding that jurisdiction existed, the Arab Republic of Egypt filed a request for the annulment of that decision on November 14, 1988. The Secretary-General acting at that time declared he did not have the power to register the requestsuch registration being necessary to trigger the annulment process-on the ground that an interlocutory decision of a Tribunal is not an "award" for the purposes of Article 52. ${ }^{44}$ As argued within, if one is concerned with an abusive delaying use of the annulment recourse, then this decision greatly circumscribed such possibilities and stabilized the ICSID review process. ${ }^{45}$

In conclusion, this outline of the framework of the ICSID annulment process does not support the process's reputation for instability. Rather, the presumed validity of awards, the availability of partial annulment, and the unavailability of interlocutory annulment all point to a basic integrity and coherence to the process.

\section{B. The Confusion of Annulment and Appeal in Article 52(1) Review}

The language of Article 52(1) itself in part engenders the confusion of annulment and appeal in the ICSID annulment process. Article 52(1) contains five grounds for annulment:

(a) that the Tribunal was not properly constituted;

(b) that the Tribunal has manifestly exceeded its powers;

(c) that there was corruption on the part of a member of the Tribunal;

43 The decision of the Acting Secretary-General in Southern Pacific Properties was foreshadowed in the refusal of the Secretary-General to register a request by the claimant for annulment of a procedural order in Holiday Inns/Occidental Petroleum v. Morocco (ICSID Case No. ARB/72/1). See 1978 ICSID Ann. Rep. at 5.

446 News From ICSID, No. 1 (1989) at 2.

45 Of course, I would think a partial award, as distinct from an interlocutory award, very well might be registerable for annulment. The key issue, as with enforcement of foreign arbitral awards of interim measures, would be whether the question addressed by the partial award is "final" and severable from the remainder of the arbitration. See, e.g., Sperry International Trade v. Israel, 532 F. Supp. 901, 906 (S.D.N.Y. 1982), aff d F. 2d 301 (2nd Cir. 1982), reprinted in 21 ILM 1066 (1982). 
(d) that there has been a serious departure from a fundamental rule of procedure; or

(e) that the award has failed to state the reasons on which it is based. Of these, the second, fourth, and fifth have been discussed in the three ad hoc Decisions. ${ }^{46}$ The meaning of these grounds for annulment is explored in the following sections.

As is apparent in all the Committee Decisions, it is with regard to the fifth and last ground that it is most difficult for the ad hoc Committee to avoid being drawn into an appeal-like, rather than annulment-like, review. In part, this is a consequence of the fact that the ground does not require that the failure be "serious" or "manifest." In part, it is, as noted in Part I, a consequence of the fact that an inquiry into whether there was a failure to state reasons can shade easily into an examination of the substantive correctness of the content of the award, thereby collapsing the inquiry of annulment into areas of inquiry generally thought to be reserved for appeal.

\section{The Interpretation of "Manifest Excess of Powers"}

In examining this ground for annulment, the ad hoc Committees essentially have considered two questions-the meaning of "manifest" and the range of areas in which the Tribunal may be said to manifestly exceed its powers.

Basically, "manifest" has been taken to mean a clear excess. "Article $52(1)$ (b) does not provide a sanction for every excess of its powers by a tribunal but requires that the excess be manifest which necessarily limits an ad hoc Committee's freedom of appreciation as to whether the tribunal has exceeded its powers." 47 "The very language of the provision demands a cautious approach: sub-paragraph (b) requires that the Tribunal's excess of powers be 'manifest.", 48

It is crucial, however, to define what range of actions will be examined for manifest excess of power. In this regard, I wish to emphasize an important and salutary transition in reasoning from the Klöckner Committee to the MINE Committee.

46. The Amco Committee in general was least inclined to distinguish and clarify the different grounds listed in Article 52. "The ad hoc Committee will deal with the various claims of nullity raised by Indonesia following the general sequence of the findings and conclusions adopted by the Tribunal in its Award, instead of grouping the specific claims under each of the three grounds for annulment set forth in the Convention." Amco Decision, supra note 17, at para. 16.

47 MINE Decision, supra note 18 , at para. 4.06.

48 Klöckner Decision, supra note 3 , at para. 3 (emphasis in original). 
The Klöckner Committee's approach assumed that a variety of actions might raise the possibility of excess of powers. ${ }^{49}$ That Committee concluded that jurisdiction was one such area:

Clearly, an arbitral tribunal's lack of jurisdiction, whether said to be partial or total, necessarily comes within the scope of an "excess of powers."

Consequently, an applicant for annulment may not only invoke lack of jurisdiction ratione materiae or ratione personae under Articles 25 and 26 of the Convention, but may also contend that the award exceeded the Tribunal's jurisdiction as it existed under the appropriate interpretation of the ICSID arbitration clause. ${ }^{50}$

It is generally accepted that jurisdiction is an area to be examined for manifest excess of powers. The Klöckner Committee, however, in accepting this premise failed to offer a conceptual reason for its validity. That lack of jurisdiction is "clearly" under Article 52(1)(b) appears, from the general tone of the opinion, to flow from general acceptance rather than articulation of a central concept. Consequently, when the Klöckner Committee considered whether failure to apply the applicable law also constitutes a manifest excess of powers it had no central concept of scope of "manifest excess of powers" to draw upon. Instead, it was drawn into considering whether Article 52(1)(b) necessarily served as a sanction for Article 42 of the Convention, the article which indicates what law the Tribunal should apply:

We shall seek instead to determine whether in its substance [annulment for failure to apply the applicable law indicated by Article 42(a)] is admissible within the framework of Article 52(1)(b), the one on excess of powers. This raises the question of the interpretation of Article 42(1) of the Washington Convention and of the consequences of a possible failure to observe it. ${ }^{51}$

The Klöckner Committee concluded that it was obvious, "and in accordance with the principles of interpretation that are recognized generally-for example by Article 31 of the Vienna Convention on the Law of Treaties,"52 that Article 52 was necessarily to be applied with reference to Article 42. According to the ad hoc Committee, to think that Article 42 provided merely suggestions as to the applicable law without sanction, would be to misinterpret it entirely, as they found it "impossible to imagine that when they drafted Article 52 the Convention's authors would have forgotten the existence of

49 Id., at para. 4. (" $[\mathrm{I}] \mathrm{t}$ must be noted that the term 'excess of powers' (excès de pouvoir) used in sub-paragraph (b) is multi-faceted: it can cover a variety of complaints formulated against the contested award").

50 Id.

51 Id. at para. 58.

52 Id. 
Article 42."53 Moreover, the Committee found this interpretation of Article 52 confirmed by non-ICSID international arbitrations dealing with nullity. ${ }^{54}$ The failure to identify the unifying concept underlying "manifest excess of powers" was replaced with the view that Article 52(1)(b) was a remedy for manifest violations of Article 42(1). (A view that would be extended to other articles.) For the Klöckner Committee, the transformation of Article 52 into the remedy for another article in the Convention would "raise the fine distinction between 'non-application' of the applicable law and mistaken application of such law." 55

The MINE Committee's discussion in this regard is more satisfying because it appropriately focussed upon language of Article 52(1) rather than overemphasizing its contextual relation to other articles, and, as a consequence, identified a concept underlying both "manifest excess of powers" and annulment. A violation of Article 42(1), either by the application of laws other than those specified by the parties, or by disregarding all laws, "would constitute a derogation from the terms of reference within which the tribunal has been authorized to function." 56 As such, if manifest, the derogation would constitute a manifest excess of powers. The Committee's emphasis is not on whether Article 42(1) was intended to be sanctioned by Article 52(1)(b), but rather is an analysis following from the central observation that (1) the "powers" of the tribunal are defined by the terms of reference in the arbitration agreement of the parties, and (2) a manifest excess of powers is a manifest derogation from such terms of reference. Consequently, "disregard of the applicable rules of law must

\footnotetext{
53 Id.

54 See id. at paras. 59, 61 (citing Orinoco Steamship Co. and North Eastern Boundary between Canada and the United States arbitrations).

55 Id. at para. 60.
}

Ultimately, in the Klöckner proceedings, the Committee rejected the argument that the Tribunal had manifestly exceeded its powers in terms of jurisdiction because "the answers [of the Tribunal] seem tenable and not arbitrary" and therefore "do not constitute the manifest excess of powers." Klöckner Decision, supra note 3, at para. 52 (emphasis in original). The Committee, however, did accept the argument that the Tribunal had exceeded its powers in terms of the applicable law because although at least facially the Tribunal appeared to rely on a "basic principle" of the law chosen by the parties, the Committee concluded that the Tribunal's decision lacked the depth required for such a crucial question. The Committee examined the Tribunal's reasoning, and found that, because it was "limited to postulating and not demonstrating the existence of a principle or exploring the rules by which it can only take concrete form," it constituted a failure to apply the law. Id. at paras. 78-79. The Committee noted that although technically the Tribunal may have provided reasons for its decision, thereby satisfying Articles 48(3) and 52(1)(e), it "act[ed] outside the framework provided by Article 42(1), applying concepts or principles it probably considered equitable," and thus violated Article 52(1)(b). Id. As to the point that the applicable law may require the application of equity, see also Amco Decision, supra note 17, at paras. 26-28.

56 MINE Decision, supra note 18 , at para. 5.03. 
be distinguished from erroneous application of those rules which, even if manifestly unwarranted, furnishes no ground for annulment." 57

In this framework of analysis, the earlier arbitrations dealing with nullity cited by Klöckner appear more on point. The Klöckner Committee noted:

In the famous Orinoco Steamship Company case, the Permanent Court of Arbitration... held that "excessive powers may consist, not only in deciding a question not submitted to the arbitrators, but also in misinterpreting the express provisions of the agreement in respect of the way in which they are to reach their decisions, notably with regard to the legislation or the principles of law to be applied."

Excess of powers may consist of the non-application by the arbitrator of the rules contained in the arbitration agreement (compromis) or in the application of other rules. Such may be the case if the arbitrator (like Umpire Barge in the Orinoco case) applies rules of local law while the arbitration agreement prescribes that he decide "on the basis of absolute equity, without regard...to the provisions of local law," or if, conversely, he reaches a solution in equity while he is required to decide in law... 58

These two citations actually support more the approach taken by the MINE Committee; namely, an examination which distinguishes manifest derogation from the terms of reference from manifest error in applying the applicable law. The former encompasses the latter, but not the reverse. ${ }^{59}$

\section{The Interpretations of "Serious Departure from a Fundamental Rule of Procedure"}

Article 52(1)(d) of the ICSID Convention provides that where there has been a "serious" departure from a "fundamental" rule of procedure, an annulment may be granted. The MINE Committee correctly stressed the meaning of the words "serious" and "fundamental." The term serious was interpreted by the Committee to require that the departure from a fundamental rule of procedure "be substantial and be such to deprive a party of the benefit or protection which the rule was intended to provide." 60 The term fundamental was

57 Id at para. 5.04 (citing 2 History of the Convention 340, 854 (1970)).

58 Klöckner Decision, supra note 3, at para. 59.

59 In fact, the drafters of the Convention contemplated that the application of law not agreed to by the parties would fall under the category of manifestly exceeding powers, but "not merely a mistake in the interpretation or application of the applicable law." The distinction was justified by the Chairman "on the ground that the arbitrators had gone against the terms of the compromis." 2 History of the Convention 518 (Pt. II, Doc. 31, Apr. 27-May 1964, Consultative Meeting of Legal Experts).

The Amco Committee also distinguished failing to apply the applicable law from mere misconstruction of that law, finding only the former to be a manifest excess of powers, the latter being a ground for appeal.

60 MINE Decision, supra note 18 , at para. 5.05. 
considered as equally essential, as the Committee made a point of noting that not all ICSID rules are to be seen as "fundamental," and if not, departure from that rule cannot result in annulment. ${ }^{61}$

The Klöckner Committee in considering challenges on this ground stated that it is possible to hold that the requirement of deliberation among the arbitrators is a "basic rule of procedure," 62 and that "[i]mpartiality of an arbitrator is a fundamental and essential requirement." 63 The Committee was least tolerant of any lack of impartiality, stating that "any shortcoming in this regard, that is any sign of partiality must be considered to constitute... a 'serious departure from a fundamental rule of procedure." "64 The Amco Committee did not clearly explain its interpretation of a serious departure. Rather, the Committee merely stated that failure to deal with one or more questions could "amount...in particular situations, to a serious departure from a fundamental rule of procedure and to a manifest excess of powers." 65

Although somewhat vague, this ground has not and likely will not be in practice a source of many annulments because the twin hurdles of "serious" and "fundamental" are quite substantial.

\section{The Interpretation of "Failure to State Reasons"}

Article 52(1)(e) provides for annulment where the award of a tribunal has failed to state the reasons on which it is based. Consideration of this important basis for annulment has centered on two issues: (1) how is the Committee to decide if there has been a failure to state reasons, and (2) is the failure to answer a question raised by a party also a failure to state reasons?

As to the first issue, all of the Committees noted that the language of the Article 52(1)(e) annulment ground of "failure to state reasons" parallels Article 48(3)'s requirement that "the award...shall state the reasons upon which

61 Id. at para. 5.06 .

62 Klöckner Decision, supra note 3, at para. 84. "It is also possible to hold that such deliberation must be real and not merely apparent." $I d$. The Committee also opined that "[e]ven if it is generally desirable for arbitrators to avoid basing their decision on an argument that has not been discussed by the parties, it obviously does not follow that they therefore commit a 'serious departure from a fundamental rule of procedure." Id. at para. 91.

$63 I d$. at para. 95. There is also discussion in Klöckner as to whether there was waiver by a party of the rule of procedure at issue inasmuch as there was not a timely objection. Id. at para. 88. Of course, if a rule of procedure is fundamental, then perhaps it should not be amenable to waiver. In this sense, failure to object is more appropriately evidence of whether there was a failure to observe the rule in question.

64 MINE Decision, supra note 18 , at para. 95.

65 Amco Decision, supra note 17, at para. 32. 
it is based." 66 The Committees disagreed, however, on how to formulate the test of such failure to state reasons.

The Klöckner Committee asked, "is it possible to liken inadequacy of reasons to a failure to state reasons?" 67 The Committee concluded that the reasons on which a tribunal bases its decision must be substantive, "allowing the reader to follow the arbitral Tribunal's reasoning, on facts and on law." 68 Furthermore, the reasons had to be relevant. In its discussion of this issue, the Committee squarely faced the distinction between appeal and annulment finding that to require "relevant reasons" could lead an ad hoc Committee towards a process of appeal, while to be satisfied with "apparently relevant" reasons would undermine the purpose of Article 52. The Committee was satisfied by the requirement of "sufficiently relevant" reasons, "that is, reasonably sustainable and capable of providing a basis for the decision." 69 The Amco Committee found the "reading of the Klöckner ad hoc Committee convincing."70

In contrast, the $M I N E$ Committee's approach was less exacting, pointedly avoiding any reference to "sufficiently relevant." The MINE Committee agreed that the reader must be able "to follow the reasoning of the Tribunal on points of fact and law,"71 but concluded that was all that was required. Any review of the adequacy of reasons

almost inevitably draws an ad hoc Committee into an examination of the substance of the tribunal's decision, in disregard of the exclusion of the remedy of appeal by Article 53 of the Convention. A Committee might be tempted to annul an award because that examination disclosed a

66 Id. at para. 114; see also Amco Decision, supra note 17, at para. 38; MINE Decision, supra note 18 , at para. 5.07 .

67 Klöckner Decision, supra note 3, at para. 117 (emphasis in original).

68 Id. at para. 119.

69 Id. at para. 120.

70 Amco Decision, supra note 17, at para. 43. The Committee noted:

If it be true that a full control and review of the reasoning followed by an ICSID tribunal would transform an annulment proceeding into an ordinary appeal, it is also true that supporting reasons must be more than a matter of nomenclature and must constitute an appropriate foundation for the conclusions reached through such reasons. Stated a little differently, there must be a reasonable connection between the bases invoked by a tribunal and the conclusions reached by it. The phrase "sufficiently pertinent reasons" appears to this ad hoc Committee to be a simple and useful clarification of the term "reasons" used in the Convention. Id.

71 MINE Decision, supra note 18 , at para. 5.08. 
manifestly incorrect application of the law, which, however, is not a ground for annulment. ${ }^{72}$

The MINE Committee considered the requirement to state reasons met if the Tribunal's line of reasoning, even if incorrect, was traceable.

One can understand why the Klöckner and Amco Committees, without a vision distinguishing annulment from appeal, may have concluded that the coincidence in language in Articles 48(3) and 52(1) implies a more exacting examination of the sufficiency of the reasons. Far more coherent with the notion of annulment, however, is the view of the MINE Committee that the finality of awards called for in Article 53 implies a very limited inquiry.

Even with the MINE Committee's test, however, it is difficult to separate the adequacy of the use of fact or law from the adequacy of the reasoning. The Committee's reference to "contradictory or frivolous reasons" emphasizes a search for either manifest incoherence in reasons (a "contradictory" relation to one another) or a manifest error in the content of a particular reason (a reason that is "frivolous"). Both grounds shade easily into appeal.

As to the second issue of whether the failure to answer a question is also a failure to state reasons, all of the Committees agreed that it was possible. The Committees disagreed, however, on when they would find annulment on this basis, and in particular focussed on clarifying the relationship between the remedy provided under Article 52(1)(e) and that provided under Article 49(2) which states:

The Tribunal upon the request of a party... may...decide any question which it had omitted to decide in the award, and shall rectify any clerical, arithmetical or similar error in the award. ${ }^{73}$

The Amco Committee interpreted Article 52(1)(e) as, in part, a sanction for Article 48(3), which requires a Committee to "deal with every question submitted to the Tribunal." 74 For the Amco Committee, Article 49(2) provided a more limited remedy, to be used to correct minor omissions, different errors than those requiring annulment as a remedy.

It may be safely assumed that arbitrators will strive in their award to express clearly at least the main reasons on which the award rests. Any omis-

72 Id. at paras. 5.08-5.09. The Klöckner Committee also agreed that contradictory reasons would constitute a failure to state reasons:

As for "contradiction of reasons," it is in principle appropriate to bring this notion under the category "failure to state reasons" for the very simple reason that two genuinely contradictory reasons cancel each other out. Hence the failure to state reasons. The arbitrator's obligation to state reasons which are not contradictory must therefore be accepted.

Klöckner Decision, supra note 3, at para. 116 (emphasis in original).

73 ICSID Convention, supra note 7 , art. 49(2).

74 Amco Decision, supra note 17 , at para. 32. 
sions of relatively minor points may be repaired pursuant to Article 49(2) by simply inserting the Tribunal's conclusions thereon in the award, the main reasoning of the award remaining unaffected by such insertion. ${ }^{75}$

The MINE Committee in contrast considered Article 49(2) the only "explicit provision" in the Convention for failing to deal with every question. For the MINE Committee the objecting party consequently should invoke Article 49(2) before seeking annulment for omissions in reasoning under Article 52:

For example, in the present case the Tribunal failed to rule on MINE's claim to be reimbursed for the cost and expenses incurred in the United States District Court and in arbitration before the American Arbitration Association in earlier stages of its conflict with Guinea. Article 49(2) would have provided a specific remedy and, not having invoked it, MINE could not have relied on the failure for purposes of annulment. ${ }^{76}$

Despite such differences in interpretation, all three Committees agreed that the remedy contained in Article 49(2) is not available when the question at issue was not one "omitted," but rather one implicitly answered by the award. "The defect complained of by Guinea could not have been cured by supplementing the Award, but would have required in effect that it be reconsidered in light of the Tribunal's decision on the "omitted' question."77

This examination of three grounds for annulment in Article 52(1), particularly as interpreted in the MINE Decision, reveals carefully limited grounds for annulment except for Article 52(1)(e) where the annulment ground of "failure to state reasons" can, if one is not careful, shade into an appeal-like inquiry of the substantive correctness of the award.

\section{The Consequences of the Existence of a Ground for Annulment}

On this final issue, the Committees again have differed and again have moved toward a better approach. The question is having found that a ground for annulment exists, what can and should the Committee do at that point? The Klöckner Committee held that the parties to an ICSID decision do not have the right to obtain annulment, since Article 52(3) states that "the Committee shall have the authority to annul the award." In other words, an ad hoc Committee has discretion to determine whether annulment is appropriate, even when grounds exist. The Klöckner Committee considered the amount of discretion allowed an ad hoc Committee to be a matter of interpretation. Rejecting

75 Id. at paras. 32, 34 (citing J. Pirrung, Die Schiedsgerichtsbarkeit nach dem Weltbankübereinkommen für Investitionsstreitigkeiten 176 (1972)).

76 MINE Decision, supra note 18, at paras. 5.11-5.12.

77 Id. at para. 5.13. Cf. Klöckner Decision, supra note 3, at para. 115; and Amco Decision, supra note 17, at paras. 35-36.

Downloaded from https://academic.oup.com/icsidreview/article-abstract/7/1/21/774375

by Univ of California Library - Bioscience \& Natural Res Library user

on 26 February 2018 
a doctrine of "no annulment without grievance,"78 the Committee concluded that, "save under exceptional circumstances," 79 the existence of any of the grounds listed in Article 52 requires annulment of the award. This aspect of the Klöckner approach was particularly singled out for attack by Professor Reisman:

The second constitutive holding was that review was to be technical and mechanical; the ad hoc Committee was to have no prudential competence.... In effect, this requirement made Article 52 into a hair-trigger, a mechanism of extraordinary sensitivity that would set off nullification at the slightest provocation without regard to the magnitude of the defect established. ${ }^{80}$

In contrast to the Klöckner approach, the MINE Committee interpreted the language of Article 52(3) to allow an ad hoc committee a limited amount of discretion, so that in cases "where annulment is clearly not required to remedy procedural injustice and annulment would unjustifiably erode the binding force and finality of ICSID awards," the older, and in my view discredited, view of the Klöckner Decision, rather than the MINE approach, that fuels those who claim the ICSID arbitration process is deteriorating.

The desirability of the Reisman and $M I N E$ approach has been confirmed by a more recent regime which seeks to avoid the difficulty posed by the Klöckner's "hair trigger" approach by creating more narrowly-crafted conditions for the annulment of a decision. In particular, annulment under the Canada-United States Free Trade Agreement (FTA) requires: (1) some type of bias or misconduct by a tribunal panel member, (2) the panel's seriously departing from a fundamental rule of procedure, or (3) the panel's manifestly exceeding its powers, and that any of these actions has "materially affected the panel's decision and threatens the integrity of the binational panel review process." 82 In other words, the FTA procedure explicitly requires that the annulment committee finds the material harm and prejudice deemed to be required for ICSID in the MINE Decision.

Having given an account of how these three ad hoc Committee Decisions have interpreted Article 52(1), I turn to an evaluation of the process as a whole.

\footnotetext{
78 Klöckner Decision, supra note 3, at para. 179.

79 Id. at para. 179.

80 Reisman, supra note 2 , at 762.

81 MINE Decision, supra note 18 , at paras. 4.09-4.10.

82 Canada-United States Free Trade Agreement, art. 1904.13, 38 U.S.T. 1934, 1959.
} 


\section{EVALUATING THE ICSID ANNULMENT PROCESS}

The concerns voiced over the ICSID annulment process are several. The dominant concern, however, is that annulment appears to be too readily available, thereby undercutting the finality of ICSID awards and greatly delaying the total process. The consequence, it is argued, is that ICSID will be a less attractive choice for dispute resolution. ${ }^{83}$ Implicitly, the specter is raised that the arbitration may proceed indefinitely-a series of annulments undoing a series of arbitrations. 84

In this Part, I argue that (1) the MINE Committee's reasoning addresses much of the concern expressed over the Klöckner and Amco Decisions; (2) an annulment process is desirable both to the parties and the international community; (3) the ICSID annulment process does not, relative to alternatives, unduly extend the process; and (4) the annulment process is particularly justified given the embryonic state of the international judiciary required to serve on arbitral tribunals such as those of ICSID.

\section{A. The Concerns Regarding the Annulment Process Have in Large Part Been Addressed in the "MINE" Decision}

The concern that annulment was too readily available was argued to stem from two flawed interpretations of Article 52(1) by the Klöckner and Amco Committees. First, the ad hoc Committee in Klöckner had held that a finding that a ground existed for annulment necessitated annulment. This holding, it was later argued, "made Article 52 into a hair-trigger, a mechanism of extraordinary sensitivity that would set off nullification at the slightest provocation without regard to the magnitude of the defect established." 85 Second, the grounds for annulment were read too broadly, particularly failure to apply applicable law as a manifest excess of powers and failure to provide "sufficiently relevant" reasons as failure to provide reasons.

The MINE Decision directly addresses these two concerns. It replaces the hair-trigger with ad hoc committees retaining a measure of discretion as to whether an award should annulled once a ground for annulment is established. It also articulates a narrower vision of how failure to apply applicable law may constitute an excess of powers, and seeks to limit "failure to state reasons" to merely reasons that "enable one to follow how the tribunal proceeded from Point A to Point B, and eventually to its conclusion, even if it made an error of fact or law." 86 Moreover, as pointed out above, this shift in reasoning should

\footnotetext{
83 See, e.g., Feldman, supra note 2.

84 Id. at 89 ("protracted proceedings that may continue indefinitely...").

85 Reisman, supra note 2 , at 762.

86 MINE Decision, supra note 18 , at paras. 5.08-5.09.
}

Downloaded from https://academic.oup.com/icsidreview/article-abstract/7/1/21/774375

by Univ of California Library - Bioscience \& Natural Res Library user

on 26 February 2018 
not be regarded to be as short-lived because the fact that ICSID itself under the ICSID Convention selects the members of ad hoc committees allows ICSID to perpetuate the $M I N E$ reasoning. As is evident from Table 2, the overlaps in composition of the last three ad hoc Committees would imply a continuance of the MINE Committee view.

Table 2

Tribunal and Committee Composition in Disputes Involving Annulment Proceedings

\begin{tabular}{lll}
\hline Proceeding & Tribunal & Ad Hoc Committee \\
\hline Klöckner I & $\begin{array}{l}\text { Eduardo Jiménez de } \\
\text { Aréchaga, Pres. }\end{array}$ & $\begin{array}{l}\text { Pierre Lalive, Pres. } \\
\text { Whmed El-Kosheri }\end{array}$ \\
& $\begin{array}{l}\text { William D. Rogers } \\
\text { Dominique Schmidt }\end{array}$ & Ignaz Seidl-Hohenveldern \\
Amco Asia I & Berthold Goldman, Pres. & Ignaz Seidl-Hohenveldern, Pres. \\
& Isi Foighel & Florentino D. Feliciano \\
& Edward W. Rubin & Andrea Giardina \\
MINE & Donald Zubrod, Pres. & Sompong Sucharitkul, Pres. \\
& Jack Berg & Aron Broches \\
& David J. Sharpe & Kéba Mbaye \\
Klöckner II & Carl F. Salans, Pres. & Sompong Sucharitkul, Pres. \\
& Jorge Castaneda & Andrea Giardina \\
& Juan Antonio Cremades & Kéba Mbaye \\
& Sanz-Pastor & \\
& Rosalyn Higgins, Pres. & Sompong Sucharitkul, Pres. \\
Amco Asia II & Marc Lalonde & Dietrich Schindler \\
& Per Magid & Arghyrios A. Fatouros \\
& &
\end{tabular}

\section{B. The Desirability of an Annulment Process}

The disputes that come before ICSID are significant, both to the parties and to the international community. This significance is illustrated with two anecdotes.

Concerning the significance to the parties, I recall a senior partner once recounting to me the unpleasant experience of advising his client, the general counsel of a major corporation, that the award in a major international arbitration-with millions of dollars in dispute- had come out against them. Needless to say, the general counsel was distressed. But after much discussion of the award, the partner could feel the shock receding and the desire to move on resurging. That's when the client instructed the partner to appeal! "But there is no possibility of appeal in the sense of U.S. courts," replied the partner. "You 
advised resolving a million dollar dispute with only one roll of the die?" queried the client.

This story emphasizes for me how the motivations of parties for agreeing to arbitration, and the expectations of those parties regarding arbitration, can, and perhaps should, differ greatly and differ particularly between the domestic and international contexts. In particular, we must return to the tension between "finality" (the desire that the dispute resolution mechanism provide a final answer to the problem) and "accuracy" (the desire that the dispute resolution mechanism provide the correct answer).

Domestically, arbitration is chosen as a hopefully faster and less expensive alternative to courts. If this is one's motivation and expectation, then the finality of the arbitral award is very important. Internationally, however, arbitration often is chosen not as an alternative to a more formal and public process, but rather because it is the only option. Particularly for politically sensitive areas such as large investment disputes, the courts of the State of either party are likely unacceptable. Choosing the courts of a third State is problematic because to ascertain whether procedurally and substantively the courts and legal system would be acceptable would take a tremendous effort. ${ }^{87}$ Thus, the parties are led to choose arbitration. Because the motivations for entering into international and wholly domestic arbitration can differ, there also perhaps should be important differences in these two forms of arbitration and in how they are evolving. In particular, if as in the story I just related the accuracy of the decision is important to the parties, then perhaps the arbitral process should be something more akin to a judicial process. Perhaps internationally there should be several forms of arbitration, some more courtlike than others, possibly even providing for a process of review approaching appeal. ${ }^{88}$ In this sense, depending upon the dispute, a party, as in the story, may care far more about the accuracy, than the finality, of the decision. Although there are some disputes, for example minor boundary disputes, where finality rather than accuracy is the dominant value, the considerations outlined above suggest that the parties, for the disputes likely to come before ICSID, should not be averse to the ICSID annulment process simply because the ground of "failure to state reasons" might lead to a limited examination of the adequacy of the reasoning.

As far as the significance to the international community, I am reminded of how many times I have run across a nation's attitude toward arbitration

87 In addition, in choosing the courts of a third State, the parties may sacrifice control over aspects of the proceedings such as language.

88 As to this difference in motivations and the implications of such differences, see Caron, The Nature of the Iran-United States Claims Tribunal and the Evolving Structure of International Dispute Resolution, 84 AJIL 104, 116 (1990); Brower, supra note 2.

Downloaded from https://academic.oup.com/icsidreview/article-abstract/7/1/21/774375

by Univ of California Library - Bioscience \& Natural Res Library user

on 26 February 2018 
generally or a specific arbitral institution being colored by some infamous arbitration which is remembered as unjust: the Latin American view of the Venezuelan Claims Commissions and their difficulty in moving beyond the Calvo doctrine; the Arab critical perception of the arbitration between Saudi Arabia and Aramco; and, most recently, the U.S. official view of the unjudicial character of the International Court of Justice's judgment in the Nicaragua case. ICSID was intended to encourage investment by providing through a neutral institution an effective remedy. In such circumstances, it would appear to me that the international community has a strong interest in every dispute being perceived as being both legitimately produced and substantively correct.

Mark Feldman expressed the concern that the annulments rendered in Klöckner and Amco would impair the "efficacy" of ICSID arbitration generally. ${ }^{89}$ What must be seen, however, is that implicit in this concern over "efficacy" is the assumption that it is more important to ICSID's being efficacious that its awards be final rather than correct. For Feldman, the Klöckner and $A m c o$ "decisions [ran] counter to the trend of international arbitration law to recognize the finality of arbitral awards." 90 Finality is important in his view because the parties value "informality, expedition and economy." 91 Indeed, in Feldman's view, "[p] arties to arbitration knowingly forego the elaborate procedural safeguards of the judicial process including...the right of appeal." 92 But Feldman's view of motivation assumes that the substantive correctness of an award for a dispute regarding a multimillion dollar turn-key contract is of little concern to the parties or the international community. Indeed, in attempting to prove his point, he implicitly recognizes that the reliance the international community has placed on the perception that ICSID arbitration is fair:

ICSID arbitration is particularly important to the governments of developing countries because it provides an exclusive procedure for the settlement of disputes with foreign investors. The capital-exporting states which have acceded to the ICSID Convention have agreed to forego diplomatic protection of their nationals in respect of disputes submitted to ICSID unless the host state fails to comply with awards, and the ICSID process is not subject to supervision by national courts. ${ }^{93}$

Moreover, Feldman's view of parties knowingly foregoing processes that would better ensure substantive correctness assumes that the parties have such other choices, that they appreciate what they forego and that they would de-

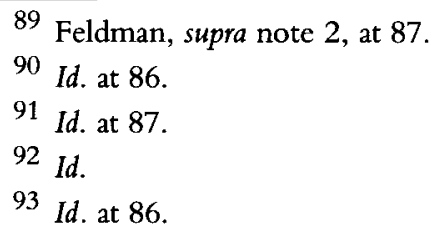


cline to opt for ICSID arbitration if a low standard of review made annulment somewhat akin to appeal. But, given the size of claims and political sensitivity of the disputes that come before ICSID, doesn't it seem equally possible that the correctness of the award is, or should be, also important both to the parties and to the international community. In this sense, it is not so much surprising to me that the annulment process is used as much as it is. To the contrary, I'm astonished that it has not been resorted to more. Given the importance of many of the disputes and, as discussed above, the occasional errors of the arbitrators, it would seem that at least the amount of review present in the annulment process provided for in Article 52, and as understood by the MINE Committee, is desirable.

\section{The Performance of the ICSID Annulment Process Relative to Altermatives to It}

It is not enough to decide that an annulment or appeal process is desirable as a general matter; although it is true that arbitration often is the only recourse, several models of arbitration other than ICSID may be chosen. Thus the question becomes whether ICSID proceedings given the recent increase in recourse to the annulment option are unduly prolonged when compared to other options, such as ICC or UNCITRAL arbitration in States such as Spain or Canada. In other words, will the consumers (the parties) choose from the consensual marketplace a mechanism other than ICSID? Unfortunately, to answer this question requires a knowledge of the relative performance of dispute resolution mechanisms that most consumers do not possess and can not readily gain.

We do know that with respect to ICSID, thirteen awards have been rendered thus far by tribunals, with the length of time between registration of the dispute and the date of the award having a low of 22 months and a mean of 36 months. ${ }^{94}$ The annulment Decisions were made considerably quicker, with a mean duration of 18 months, and a range of 13 to 23 months. In attempting to compare this record with the performance of other mechanisms, it should be assumed that the importance of many investment disputes to both the investor and State involved will drive those parties to explore and possibly use all available legal and political devices in any proceeding. Thus we must inquire not how all disputes fare elsewhere, but how disputes of such sensitivity fare in alternative forums. While many of the ICSID disputes are relatively important, political and thus heavily litigated disputes, international commercial arbitrations generally - for example, ICC arbitrations - are not necessarily of equal size or importance. Indeed, ICC arbitrations often do

94 The longest period was 63 months. See Table 1 . However, this fact is not particularly significant given that much of this extended period was as a result of the wishes of the parties rather than a slow process. The very recent award in the Southern Pacific Properties arbitration is not included in this calculation.

Downloaded from https://academic.oup.com/icsidreview/article-abstract/7/1/21/774375

by Univ of California Library - Bioscience \& Natural Res Library user

on 26 February 2018 
not involve States or State agencies at all. Thus comparisons are difficult because it is only a small subset of ICC arbitrations that likely are of equal sensitivity. It must also be remembered that the comparison should be made not only from the date of initiation to the date of award, but rather extend to the date of enforcement.

With these methodological points in mind, the preference toward ICSID is apparent for me from the observation that given disputes of equal value and sensitivity, arbitration other than before ICSID presents many more opportunities than ICSID for delay simply because of the many jurisdictions potentially involved. As Judge Charles N. Brower recently observed:

The creativity and resourcefulness increasingly displayed by parties seeking annulment in national courts of awards against them, or resisting their enforcement under the New York Convention, is often stupefying. I need only recall my own involvement in recent times in an I.C.C. arbitration that wound up in annulment proceedings in the Paris Cour d'Appel and the French Cour de Cassation; in several actions in lower courts and two proceedings in the Federal Tribunal (Supreme Court) of Switzerland; in several lower court and appellate proceedings in Belgium; and in four separate actions in court in the Cayman Islands, one leading to an application for a stay before a single judge of the Cayman Islands Court of Appeals. ${ }^{95}$

The force of international commercial arbitral awards outside of the ICSID regime generally may be attacked not only in the courts of the State where the award was rendered, but also in the courts of those States where enforcement or recognition is sought. ${ }^{96}$ In addition, the proceedings in those courts may be subject to appeal. ${ }^{97}$ In contrast, the ICSID system provides only one opportunity for that type of attack - the annulment proceeding under discussion. In ICSID, "[t]he award...shall not be subject to any appeal or to any other remedy except those provided for in this Convention." 98 The contracting States must enforce the ICSID award "as if it were a final judgment of a court in that State." 99 All this is not to say that ICSID need not be improved but rather that in the marketplace of mechanisms available for disputes of the complexity and sensitivity inherent in ICSID's scope of jurisdiction, the ICSID process "remains the most streamlined."100

95 See Brower, supra note 2, at 8. See also Craig, The Uses and Abuses of Appeal from International Arbitration Awards in Symposium on Private Investors Abroad-Problems and Solutions in International Business in 1987 at 14-1, 14-64, 14-65 (J. Moss ed., 1987).

96 Furthermore, the national courts proceedings associated with international commercial arbitration can result in the setting aside or the refusal to enforce an award on the ground that the award is contrary to the "public policy" of the State involved.

97 See Branson, supra note 2, at 28.

98 ICSID Convention, supra note 7 , art. 53(1).

99 Id. at art. 54(1).

100 Branson, supra note 2, at 28. 


\section{Annulment and the Development of an International Judiciary}

The real issue posed by the ICSID annulments is not their potential for delay of the process, but rather their revelation of the capacity for error by respected arbitrators. As argued above, some control process for awards should be desirable both to the parties and the community, and the ICSID process likely performs as well, if not better, than the alternatives to it. In this sense, I see the ICSID annulments as manifesting a deeper issue concerning the quality of the international arbitral decision-making process generally. In Klöckner, there first was astonishment that the arbitrators rendered an award in such an important dispute on such dubious and vague equitable grounds. ${ }^{101}$ There second was astonishment that the annulment panel went far beyond its task in expounding on the annulment process generally. Both judicial competence and judicial restraint appeared lacking, which in turn undercut ICSID's international reputation.

As political and economic integration continues apace, the more complex international relationships will rest upon an increased creation of and recourse to institutions like ICSID, GATT panels or arbitration such as that under the U.S.-Canada Free Trade Agreement. As the American Arbitration Association and the American Bar Association Code of Ethics for Arbitration notes: "The use of commercial arbitration to resolve a wide variety of disputes has grown extensively and forms a significant part of the system of justice which our society relies upon for the fair determination of legal rights." 102 The question, however, is from where will the international judiciary necessary to staff these mechanisms come? Can the cadre of international commercial arbitrators fill this role? Can improved selection processes yield those that can? Professor Reisman points out that some "controls" on a dispute resolution mechanism are not external like the ICSID annulment process, but rather internal-for example, in the form of ethics. ${ }^{103}$ Does the

101 Branson, supra note 2, at 25 ("the initial 'final awards' were [issued by] lawyers of stature in the field.... That the awards issued by these arbitrators were found wanting for failure to apply applicable law and required annulment was considered surprising indeed").

102 American Arbitration Association/American Bar Association, Code of Ethics for Arbitration in Commercial Disputes (adopted 1977), reprinted in 10 Y.B. Com. Arb. 132 (1985). See generally Holtzmann, Introductory Note, 10 Y.B. Com. Arb. 131 (1985).

103 Reisman, supra note 2, at 741 ("Internal legal systems of control have ranged from the inculcation, certification, and application of craft skills by key actors to collegiate decision structures in which tasks and roles are distributed among a number of participants, as well as to the insistence that decisions be accompanied by the manifest reasoning on which they were based as a way of monitoring cameral deliberations, to peer pressure, and to devices such as reliance on supernatural intervention (for example, by the use of oaths or rituals)". 
present cadre of international commercial arbitrators represent such a community? ${ }^{104}$

Moreover, we have no reason to believe that a more exacting annulment or appeal process would remedy this situation. Why should we think that a second panel of three arbitrators will yield a better decision than the first panel of three arbitrators? The key for the foreseeable future will be that the review panel answer a question different from that answered by the original tribunal. If the tribunal was confronted with deciding whether it possessed jurisdiction, the review panel should consider whether the decision as to jurisdiction was manifestly wrong. In other words, the standard of review should be used to keep the primacy of decision with the initial tribunal since there is little reason to believe that the review panel's decision would be more accurate. The review panel thus exists primarily to deal with the grossly aberrant decision. Whether the examination of aberrance is with regard only to the legitimacy of the process, or also with regard to the substantive correctness of the award, is a separate question.

The development of an international judiciary is the greatest challenge ahead for international dispute resolution and, as a consequence, the evolution of any more complex ordering of the world. Supervisory processes, such as the ICSID annulment recourse, will be an important part of the development of this judiciary and its concomitant international reputation. That they are utilized perhaps indicates how necessary they are. ${ }^{105}$

104 Indeed, a number of people in the international arbitration community have expressed to me the belief that the lack of judicial restraint in the early ICSID annulment decisions may be seen as evidence of the competition, rather than community, among international arbitrators. In particular, the argument would be that given that the international arbitrator community is small, that they generally all operate at the "trial" level, and that they in a sense have all been in competition for years for selection as arbitrators, there would be an understandable tendency for an arbitrator placed in the position of reviewing another arbitrator's award to be critical of that award. Although this argument in a sense rings true, I have my doubts. In particular, it must be remembered that the reviewing arbitrator operates in a panel with other arbitrators, a circumstance that should mitigate against such a tendency. The general point, however, does lead to the suggestion that an institution such as ICSID should consider how it might develop a list of arbitrators willing to serve exclusively at the review level. In the case of the GATT, the "Draft Final Act Embodying the Results of the Uruguay Round of Multilateral Trade Negotiations," MTN.TWC/W/FA (Dec. 20, 1991), which envisions a true appeals process, would establish a standing appellate body composed of a pool of seven members serving four year terms and not participating "in the consideration of any disputes that would create a direct or indirect conflict of interest."

105 See MINE Decision, supra note 18, at para. 4.12. ("MINE's argument wrongly assumes that frequent annulments will necessarily be the result of overly strict tests.... It overlooks the possibility that such frequent annulments reflect neglect by arbitrators, parties or counsel..."); Brower, supra note 2 , at 9 ("The overall effect of this control mechanism should be to instill in ... the arbitrators, the consciousness that they must do their duty in full or their work may indeed be upset").

Downloaded from https://academic.oup.com/icsidreview/article-abstract/7/1/21/774375

by Univ of California Library - Bioscience \& Natural Res Library user

on 26 February 2018 


\section{Appendix}

Drafting History of Article 52 (1) of the ICSID Convention

Stage
Final Text
Either party may request annulment of the award by an
application in writing addressed to the Secretary-General
on one or more of the following grounds:
a) that the Tribunal was not properly constituted;
b) that the Tribunal has manifestly exceeded its powers;
c) that there was corruption on the part of a member of
d) the Tribunal;
e) there has been a serious departure from a funda-
which it is based.

First Draft

Either party may request annulment of the award by an application in writing addressed to the Secretary-General on one or more of the following grounds:
a) that the Tribunal was not properly constituted;
b) that the Tribunal has manifestly exceeded its powers;
c) that there was corruption on the part of a member of the Tribunal;
d) that there has been a serious departure from a funda- mental rule of procedure; or
e) failure to state the reasons for the award, unless the parties have agreed that reasons need not be stated.

Revised Draft

Either party may request annulment of the award by an application in writing addressed to the Secretary-General on one or more of the following grounds:
a) that the Tribunal was not properly constituted;
b) that the Tribunal has manifestly exceeded its powers;
c) that there was corruption on the part of a member of the Tribunal;
d) that there has been a serious departure from a funda- mental rule of procedure; or
e) that the award has failed to state the reasons on which it is based.


Preliminary Draft, The validity of an award may be challenged by either taken from Article party on one or more of the following grounds:

30,1955 Int'l Law a) that the Tribunal has exceeded its powers;

Comm. Draft

b) that there was corruption on the part of a member

Convention of the Tribunal; or

on Arbitral

c) that there has been a serious departure from a

Procedure. fundamental rule of procedure, including failure to state the reasons for the award. 